\title{
Исследование способности дрожжей Saccharomyces cerevisiae к образованию технологически значимых соединений
}

\author{
Динаханум Абиляевна Абдуллабекова, канд. техн. наук, вед науч. сотр. лаборатории биохимии и биотехнологии, \\ dina2407@mail, https://orcid.org/0000-0001-9425-4551; \\ Елена Селимовна Магомедова, канд. биол. наук, вед науч. сотр., лаборатории биохимии и биотехнологии, \\ milena2760@rambler.ru; \\ Расул Закирович Гасанов, мл. науч. сотр. лаборатории биохимии и биотехнологии, gacanov@bk.ru \\ Федеральное государственное бюджетное учреждение науки Прикаспийский институт биологических ресурсов, Россия, г. Махачкала, ул. \\ М.Гаджиева, 45
}

В статье представлены результаты изучения новых штаммов дрожжей S. cerevisiae, выделенных из популяций, обитающих в условиях виноградников и мест ферментации в Дагестане. Культуры (14 штаммов), изолированные накопительным способом, идентифицированы на основе анализа нуклеотидных последовательностей ITS1-5.8SITS2 региона и D1/D2 доменов региона 26S (LSU) рДНК. Штаммы хранятся в коллекции дрожжей лаборатории биохимии и биотехнологии Прикаспийского института биоресурсов, а также в коллекции дрожжей кафедры биологии почв факультета Почвоведения МГУ. Дрожжи культивировали в питательной среде, приготовленной на азотной основе (YNB) с добавлением 15,0 г/100 $\mathrm{cm}^{3}$ глюкозы. После окончания брожения в среде определяли технологически значимые соединения - летучие кислоты, титруемые кислоты, диоксид серы $\left(\mathrm{SO}_{2}\right)$ а также суммарную антиоксидантную активность (САA). Метаболизм всех штаммов характеризовался образованием летучих, титруемых кислот и диоксида серы в пределах 1,2-

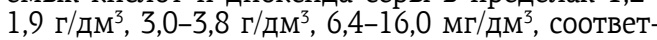
ственно. САА, в зависимости от физиолого-биохимических свойств культуры, возрастала, снижалась или оставалась неизменной. Отмечена тенденция - штаммы, продуцировавшие более 10,0 $\mathrm{M \Gamma} /$ дм $^{3} \mathrm{SO}_{2}$, способствовали росту антиоксидантной активности среды, при этом прямой зависимости между этими величинами не наблюдали. Показано, что значительное количество штаммов (>80,0\%), в том числе изолированных из природы, проявили устойчивость при содержании в среде 100 мг/дм

Ключевые слова: летучие кислоты; титруемые кислоты; диоксид серы $\left(\mathrm{SO}_{2}\right)$; суммарная антиоксидантная активность.

$\mathrm{B}$ ведение. Среди многообразия Арожжей, распространенных на виноградниках, важным объектом исследования остаются культуры S. cerevisiae. Изомяция из природных мокусов $S$. cerevisiae, используемых во всем мире в качестве ферментаторов при производстве вин, реацьный путь Аля поиска штаммов, способных эффективно воздействовать на формиро-

\footnotetext{
Как цитировать эту статью: C.143-146. DOI 10.35547/IM.2019.21.2.013

\section{How to cite this article:} DOI 10.35547/IM.2019.21.2.013

удК 634.8: 663.125:663.253.

Поступила 01.05.2019

Принята к публикации 16.05.2019

ПАниторы, 2019
}

Абдуллабекова Д.А., Магомедова Е.С., Гасанов Р.3. Исследование способности дрожжей Saccharomyces cerevisiae образованию технологически значимых соединений "Магарач». Виноградарство и виноделие, 2019; 21(2).

Abdullabekova D.A., Magomedova E.S., Gasanov R.Z. Analysis of the ability of Saccharomyces cerevisiae to form technologically significant compounds. Magarach. Viticulture and Winemaking, 2019; 21(2). pp. 143-146.
O R I G I N A L A R T I C L E

\section{Analysis of the ability of Saccharomyces cerevisiae to form technologically significant compounds}

Dinakhanum Abilyayevna Abdullabekova, Elena Selimovna

Magomedova, Rasul Zakirovich Gasanov

Federal State Budget Scientific Institution Caspian Institute of Biological

Resources, Dagestan Scientific Center, Russian Academy of Sciences, 45, M.

Gadzhieva st., Makhachkala, Russia 367000

The article presents study findings on new S. cerevisiae yeast strains isolated from the populations found in the vineyards and fermentation sites of Dagestan. The cultures (14 strains) isolated by cumulative method were identified based on analysis of the nucleotide sequences of the ITS1-5.8S-ITS2 region and D1/D2 domains of the $26 \mathrm{~S}$ region (LSU) of rDNA. The strains are stored in the yeast collection of the laboratory of biochemistry and biotechnology of the Caspian Institute of Bioresources, as well as in the yeast collection of the Department of Soil Biology of the Faculty of Soil Science, Moscow State University. The yeasts were cultivated in a nutrient medium prepared on a nitrogen basis (YNB) with the addition of $15.0 \mathrm{~g} / 100 \mathrm{~cm}^{3}$ of glucose. After the end of fermentation in the medium, technologically significant compounds were determined - volatile acids, titrated acids, sulfur dioxide $\left(\mathrm{SO}_{2}\right)$, and total antioxidant activity (CAA). The metabolism of all strains was characterized by formation of volatile, titratable acids and sulfur dioxide in the range of $1.2-1.9 \mathrm{~g} / \mathrm{dm}^{3}, 3.0-3.8 \mathrm{~g} / \mathrm{dm}^{3}, 6.4-$ $16.0 \mathrm{mg} / \mathrm{dm}^{3}$, respectively. Depending on the physiological and biochemical properties of the culture, CAA increased, decreased or remained unchanged. The tendency was registered of the strains producing more than $10.0 \mathrm{mg} / \mathrm{dm}^{3}$ $\mathrm{SO}_{2}$ to stimulate the antioxidant activity of the medium, while no direct correlation was observed between the values. It is demonstrated that a significant number of strains $(>80.0 \%)$, including those isolated from nature, showed stability when the content of free sulfur dioxide in the medium was $100 \mathrm{mg} / \mathrm{dm}^{3}$. Key words: volatile acids; titratable acids; sulfur dioxide $\left(\mathrm{SO}_{2}\right)$; total antioxidant activity.

вание типа и качества вин разных категорий. Изучение техномогической ценности Арожжей традиционно вкмючает как исследование их способности к продуцированию диоксида серы, так и устойчивости к $\mathrm{SO}_{2}$, применяемому в виноделии на всех этапах технологического цикца с учетом его антимикробных, антиокислительных, экстрагирующих и Аругих свойств.

В зависимости от штаммовых особенностей находится образование количества метучих кислот, Аопустимая концентрация которых в готовых винах регламентируется и поэтому это свойство учитывается при выборе стартовых культур.

В последние годы большое внимание уделяется определению антиоксидантной активности как интеграцьного показателя нового виАа качества биологической ценности вин [1-4]. САА может скмадываться как из антиоксидантов винограАа, в первую очередь фенольных соединений, так и компонентов, синтезируемых Арожжами.

В последнее время Арожжи вызывают интерес как объекты, способные синтезировать антиоксиАанты, которые, явцяясь природными соединениями, могут заменить синтетические. Тестирование Арожжей, полученных несколькими способами на разных средах, показал их способность продуцировать соединения, обладающие антиоксидантной активностью. В каче- 
стве высокоактивных продуцентов авторы выдемяют штаммы Hansenula anomala и Rhodotorula glutinis [5].

Антиоксидантные свойства вин и дрожжей в основном связывают с высокомолекулярными соединениями. Установцено, что к ним относятся, например, соединения, имеющие в своем составе SH-группы (глутатион, серосодержащие аминокислоты) ими ароматические коцьца, связанные с одной ими несколькими гиАроксимьными группами [6]. В послеАние годы большое внимание уделяется вопросу продуцирования Арожжами $S$. cerevisiae мематонина, явцяющегося мощным антиоксидантом, отмечается зависимость его образования от штаммовой принаАлежности $[7,8]$. Кроме того известно, что антиоксидантные свойства проявцяют многие низкомолекулярные соеАинения, значение которых повышается в условиях, когАа ферментативная антиоксидантная активность становится неэффективной. К ним относятся разАичные по структуре и химическим свойствам соединения, способные взаимодействовать с кислородными и органическими радикацами и ингибировать протекание свободнорадикацьных процессов в кметках, оАним из них явцяется АиоксиА серы $[9,10]$.

Недавно было открыто, что $\mathrm{SO}_{2}$ относится к газотрансмиттерам (газовые медиаторы) - эндогенно синтезируемым молекулам газов, выполняющим в организме важные кметочные функции, которые до выявления их природы быми известны мишь как токсические вещества. Газовые медиаторы составцяют еАиный комплекс веществ и явАяются новым виАом биорегуляторов [11]. Бымо обнаружено, что АиоксиА серы эндогенно образуется в серАечно - сосудистой системе [12]. Открытие эндогенного $\mathrm{SO}_{2}$ у миекопитающих обнаружимо его протекторное Аействие - антиоксидантное, противовоспацитемьное, антигипертензивное и антиатерогенное [13].

Аиоксид серы как натурацьный побочный продукт брожения явцяется также промежуточным метабомитом Арожжей на пути ассимимяции сульфатов, привоАящим к синтезу серосодержащих аминокислот [14]. Выдемение дрожжами $\mathrm{SO}_{2}$ наблюдается как при аэробных, так и анаэробных условиях, зависит от расы дрожжей и тесно связано с энергетическими процессами, происходящими в киетке. Накопление диоксида серы при сбраживании винограАного сусла зависит от исходной сахаристости, $\mathrm{pH}$, температуры брожения [15].

Цемь работы: тестирование Арожжей $S$. cerevisiae на способность к образованию диоксида серы, метучих и титруемых кислот, суммарной антиоксидантной активности в зависимости от штамма.

\section{Материалы и методы исследования}

Объекты исследования: штаммы Арожжей $S$. cerevisiae, выдеменные из попумяций, обитающих в условиях виноградников и мест ферментации в Аагестане [16, 17].

Все штаммы генетически идентифицированы и хранятся в комлекции Арожжей маборатории биохимии и биотехнологии Прикаспийского института биоресурсов, а также в коммекции Арожжей кафеАры биомогии почв факумьтета Почвоведения МГУ.

При изучении метаболизма Арожжей применями сбацансированную по питатецьным веществам среАу,

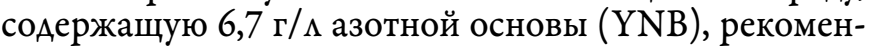

Ауемую в $и$ итературе [18], куда Аобавмяли глюкозу в количестве - 15,0 г/100 см³. Микрозасев биомассы Арожжей осуществцями микробиологической петмей (0,03-0,05 см), ферментацию проводими при темпертуре $22-23^{\circ} \mathrm{C}$, контромь осуществлями визуамьно. После окончания ферментации культурацьную жидкость Аекантироваци с упмотненного Арожжевого осаАка и измеряли в ней массовую концентрацию антиоксиАантов. Контрольным вариантом служима исходная среда, где САА за счет входящих в ее состав аминокислот - метионина, который явцяется признанным природным антиоксидантом, триптофана, витаминов, микроэлементов была на уровне 22,6 мг/Aм ${ }^{3}$.

При изучении устойчивости штаммов к свободной $\mathrm{SO}_{2}$ в среду вводими разрешенный ГОСТом Р549562012 пиросуиьфит кация $\left(\mathrm{K}_{2} \mathrm{~S}_{2} \mathrm{O}_{5}\right)$ в количестве, обеспечивающем концентрацию свободного Аиоксида серы 100,0 мг/Aм ${ }^{3}$. Массовую концентрацию сахаров и титруемых кислот опрАелями по ГОСТам Р 13192-73 и Р 32114-2013 соответственно, Аиоксида серы и $е$ етучих кислот, объемную Аолю спирта по методикам, принятым в энохимии [19].

Суммарную антиоксиАантную активность измеряли на приборе ЦВЕТ ЯУЗА 01-АА, используя граАуировочный график зависимости выходного сигнаца от концентрации гамиовой кислоты [20].

Тестирование исследуемых штаммов на устойчивость к АиоксиАу серы экзогенного происхожАения Арожжей вида $S$. cerevisiae проводими на среде, приготовценной на азотной основе с массовой концентрацией сахаров - 5,0 г/100 см ${ }^{3}$ и свободного Аиоксида серы - $100 \mathrm{Mг} / \mathrm{AM}^{3}$.

\section{Результаты исследований и их обсуждение}

Комичество титруемых и метучих кислот является обязательным при характеристике вин и регламентируется ГОСТами и технологическими инструкциями А я разцичных типов.

Так, в столовых винах Аопустимое количество ти-

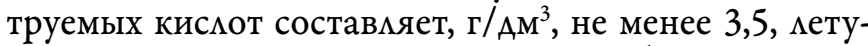
чих кислот варьирует предемах 0,9-1,2 (ГОСТ 32030 2013). В игристых винах титруемая кислотность Аолжна находиться в интерваце, г/Aм ${ }^{3}-5,0-8,0$, метучих кислот 1,0-1,2 (ГОСТ 33336-2015).

О способности опытных культур регулировать кислотность среАЫ сУАили по массовой концентрации титруемых и метучих кислот в образцах, полученных с их участием, которая согласно Аанным, преАстав енным в таблице, возрастаца во всех вариантах.

Продуцирование метучих кислот варьировано в пределах 1,2-1,9 г/Ам ${ }^{3}$, минимамьная концентрация отмечена в вариантах, полученных с использованием штаммов 226, 256, максимацьная - 255, 285, выдеменных из виноградников. Генерирование титруемых

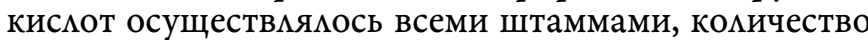
зависело от их индивидуацьных особенностей и нахоАимось в преАе ах 3,0-3,8 г/Ам³.

Способность к образованию эндогенного АиоксиАа серы отмечами во всех опытах, его концентрация зависела от свойств штамма и варьироваца в интерваце $6,4-16,0 \mathrm{Mr} / \mathrm{AM}^{3}$.

Анациз величины антиоксидантной активности среды показац как стабимьность, так и разцичную направценность ее изменения при брожении (рис.1). 
Таблица. Массовая концентрация летучих, титруемых кислот, диоксида серы Table. Mass concentration of volatile, titratable acids, sulfur dioxide

\begin{tabular}{|c|c|c|c|c|c|c|c|c|c|c|c|c|c|c|c|}
\hline \multirow{3}{*}{ Показатели } & \multicolumn{15}{|c|}{ Культурамьная среда } \\
\hline & \multirow{2}{*}{$\begin{array}{l}\text { исхоА- } \\
\text { ная }\end{array}$} & \multicolumn{14}{|c|}{ посме ферментации на штаммах } \\
\hline & & 226 & 232 & 248 & 249 & 250 & 251 & 252 & 253 & 255 & 256 & 283 & 285 & 295 & 298 \\
\hline Титруемые кислоты, г/Ам & 0,5 & 3,2 & 3,5 & 3,4 & 3,5 & 3,2 & 3,5 & 3,5 & 3,5 & 3,3 & 3,1 & 3,5 & 3,8 & 3,0 & 3,7 \\
\hline Иетучие кисмоты, г/Ам ${ }^{3}$ & 0,0 & 1,2 & 1,6 & 1,4 & 1,4 & 1,3 & 1,6 & 1,3 & 1,6 & 1,9 & 1,2 & 1,7 & 1,9 & 1,4 & 1,4 \\
\hline $\mathrm{SO}_{2}, \mathrm{Mr} / \mathrm{AM}^{3}$ & 0,0 & 12,8 & 12,8 & 16,0 & 6,4 & 6,4 & 12,8 & 10,2 & 8,9 & 6,4 & 6,4 & 12,8 & 15,4 & 11,5 & 15,4 \\
\hline
\end{tabular}

Снижение значения этого показателя отмечено в вариантах с использованием штаммов - 249, 255, 256,295 , возрастание - 298, 285, 248, 251, 232, 252, 283,226, в образцах - 250, 253 она практически не изменимась. Известно, что функция антиоксидантных систем закцючается в созАании оптимацьного уровня активных форм кислорода (АФК), основным местом образования которых при аэробиозе явцяются митохонАрии киеток, замещаемые в анаэробиозе промитохонАриями с реАуцированными функциями [21, 22].

РазАичная направленность изменения САА, очевиАно, обусловлена физиолого-биохимическими свойствами штаммов, вАияющими на состав антиоксидантов, который может скмадываться из компонентов среды, полностью не используемых при ферментации, а также метаболитов разАичной химической природы и возожно ферментов, проАуцируемых культурами.

Сравнитемьный анациз интеграцьной антиоксидантной активности куцьтурацьной жиАкости и уровня образования эндогенного Аиоксида серы, оАного из компонетов САА, показац опредеменную тенАенцию - в 8 вариантах из 9 (штамм 295),

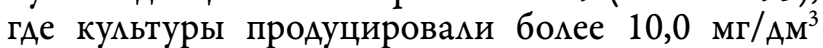
$\mathrm{SO}_{2}$, отмечался рост антиоксидантной активности по сравнению с исходной среАой (рис. 2). При этом прямой зависимости межАу суммарной антиоксиАантной активностью и количеством АиоксиАа серы не отмечацось, что объяснимо многокомпонентностью среАы, структурой и взаимодействием ее составцяющих, а также тем, что в САА участвует только свободная форма Аиоксида серы.

Аля винных Арожжей АиоксиА серы явцяется, в основном, не фунгициАным, а фунгистатическим средством. Аоза вводимого $\mathrm{SO}_{2}$ в качестве превентивной меры зависит от степени зрелости и санитарного состояния винограда, величины рН и температуры сусла.

КогАа винограА симьно поврежАен и температура сусла больше $20^{\circ} \mathrm{C}$, его концентрация АовоАится Ао 150-200 г/АM ${ }^{3}$ [23].

Аиоксид серы оказывает непосредственное негативное воздействие на Арожжевые клетки. Уже в малых Аозировках, проникая через плазматическую мембрану, он приводит к быстрому расщеплению в кметке тиамина и менее выраженных тиаминфосфата и тиаминпирофосфата. При этом в большей ими меньшей степени инактивируются зависящие от тиаминпирофосфата ферменты - пируватдекарбоксимаза и транскаталаза и снижается содержание АТФ [24].

При тестировании штаммов на устойчивость

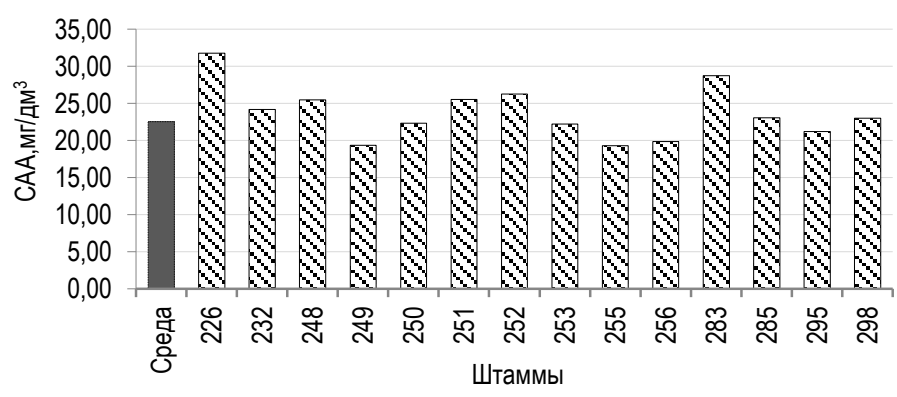

Рис. 1. Суммарная антиоксидантная активность среды при культивировании разных штаммов S. cerevisiae

Fig. 1. The total antioxidant activity of the medium during cultivation of different of $S$. cerevisiae strains

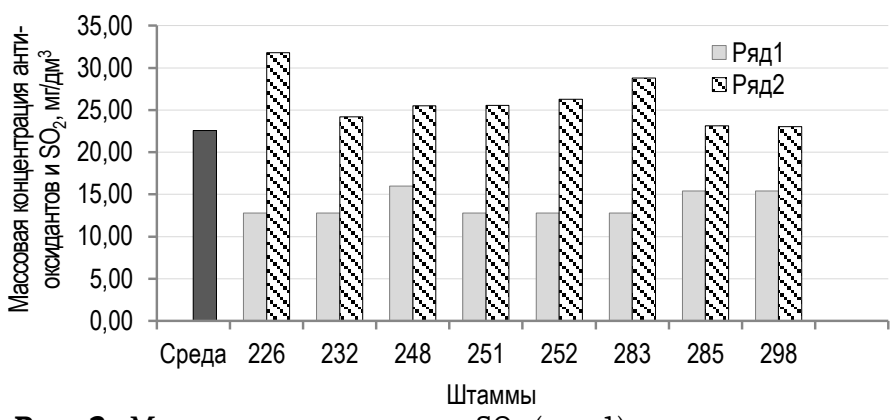

Рис. 2. Массовая концентрация $\mathrm{SO}_{2}$ (ряд 1) и антиоксидантов (ряд 2) среды при культивировании разных штаммов S. cerevisiae Fig. 2. Mass concentration of $\mathrm{SO}_{2}$ (row 1) and antioxidants (row 2) of the medium during cultivation of different $S$. cerevisiae strains

к Аиоксиду серы опыт ставици в Авух повторностях, в каждом варианте отмечами начацо брожения, набцюдение вели в течение 14 дней. Полученные данные показа$\Lambda$, что из 14 протестированных культур, устойчивость к Аействию $\mathrm{SO}_{2}$ проявици 12 штаммов, среАи которых - 283, 285, 232, 250, 252, 253 характеризовамись бомее кратким периодом аАаптации.

Выводы. Штаммы дрожжей $S$. cerevisiae, выдеменные из разцичных местообитаний, при кумьтивировании на сбамансированной по питатемьным компонентам синтетической среде (YNB), проявими способность к образованию $е т у ч и х ~ к и с л о т ~ в ~ п р е д е ~ а х ~ 1,2-1,9 ~ г / А M^{3}$ и титруемых в интерваце 3,0-3,8 г/Aм ${ }^{3}$. Синтез энАогенного Аиоксида серы бым характерен Аля всех кумьтур и комебался в интерваце 6,4-16,0 мг/Aм³. Выявмено, что при брожении штаммы, в зависимости от физиолого-биохимических свойств, вносици разАичный вкАаА в антиоксиАантную активность среды. В вариантах, гАе уровень продуцируемого $\mathrm{SO}_{2}$ превышам 10,0 мг/AM${ }^{3}$, отмечена тенденция к росту САА, при этом прямой зависимости межАу этими величинами не набцюдали.

Показано, что при содержании в среде свободного Аиоксида серы на уровне $100 \mathrm{mг} / \mathrm{Am}^{3}$ более 80,0\% штаммов, в том числе выАеленные из природы, проявики 


\section{устойчивость.}

Полученные данные расширяют сведения о способности эукариотной кметки к образованию $\mathrm{SO}_{2}$, кислотного комплекса, регулированию антиоксиАантой активности среАЫ и позволяют вести скрининг культур Аля Аамьнейшего изучения их в качестве стартовых при производстве вин.

\section{Источник финансирования}

Не указан.

Financing source

Not specified.

\section{Конфликт интересов}

Не заяв ен.

\section{Conflict of interests}

\section{Not declared.}

\section{Список литературы / References}

1. Ульянова Е.В. Высокоэффективная жидкостная хроматография в исследовании антиоксидантных свойств вин // Сорбционные и хроматографические процессы. 2010. Т. 10. Вып. 4. С. 522-532.

Ul'yanova Ye.V. Vysokoeffektivnava zhidkostnaya khromatografiya $v$ issledovanii antioksidantnykh svoystv vin // Sorbtsionnyye $i$ kbramotograficheskive protsessy. 2010. Vol. 10. Issue 4, pp. 522-532. (in Russian)

2. Андриевская Д.А. Совершенствование технологии столовых вин на основе регулирования их протекторных свойств: авторефр. дис. ... канд. техн. наук. М., 2009.

Andrievskaya D.A. Sovershenstvovanie tekhnologii stolovyh vin na osnove regulirovaniva ib protektornyb svojstv: avtoref. dis. ... kand. tekhn. nauk. M., 2009.

3. Бежуашвили М.Г.. Месхи М.Ю., Бостоганашвили М.В., Малания М.А. Антиоксидантная активность виноматериалов для вин кахетинского типа и ее зависимость от фенольных соединений // Виноделие и виноградарство. 2005. № 6. С. 28-29.

Bezhuashvili M.G.. Meskhi M.Yu., Bostoganashvili M.V., Malaniva M.A. Antioksidantnaya aktivnost' vinomaterialov dlya vin kabetinskogo tipa $i$ ee zavisimost' ot fenol'nyb soedinenij // Vinodelie $i$ vinogradarstvo. 2005. № 6. pp. 28-29. (in Russian)

4. Агеева Н.М., Маркосов В.А.,. Музыченко Г.Ф и др. Антиоксидантные и антирадикальные свойства красных виноградных вин // Вопросы питания. 2015. Т. 84. № 2. С. 63-67.

Ageeva N.M., Markosov V.A., Muzychenko G.E et al. [Antioxidant and antiradica properties of red grape wines]. Voprosy pitaniia. 2015. Vol. 84. № 2. pp. 63-67. (in Russian)

5. Gazi M.R, Hoshikuma A, Kanda K. et al. Detection of free radical scavenging activity in yeast culture. 2001 Saga Daigaku Nogakubu Iho 86:67-74.

6. Щербаков С.С., Потий В.С., Солодянникова Е.А. Образование серосодержащих соединений сульфтоустойчивыми штаммами дрожжей // Известия Вузов. Пищевая технология. 1993. № 3-4. С. $23-25$.

Scherbakov S.S., Potij V.S., Solodvannikova E.A. Obrazovanie serosoderzhashchib soedinenij sul'ftoustojchivymi shtammami drozbzhej // Izvestiya Vuzov. Pishchevaya tekhnologiva. 1993. № 3-4. pp. 23-25. (in Russian)

7. Rodriguez C., Mayo J.C., Sainz R.M. et al. Regulation of antioxidant enzymes: A significant role for melatonin // Journal of Pineal Research. 2004. 36 (1). pp. 1-9.

8. Fernandez-Cruz E., Elvarez-Fernandez M.A., E.Valero et al. Melatonin and derived l-tryptophan metabolites produced during alcoholic fermentation by different wine yeast strains // Food Chemistry. 2017. Vol. 217. P. 431-437.

9. Кения М.В., Лукаш А.И., Гуськов Е.П. Роль низкомолекулярных антиоксидантов при окислительном стрессе // Успехи соврем. биологии. 1993. Т. 113. С. 456-467.

Keniva M.V., Lukash A.I. Gus'kov E.P. Rol' nizkomolekulyarnyb antioksidantov pri okislitel'nom stresse // Uspekbi sourem.biologii. 1993. Vol. 113. pp. 456-467. (in Russian)

10. Половникова М.Г. Активность компонентов антиоксидантной защиты и полифенолоксидазы у газонных растенийв онтогенезе в условиях городской среды // Физиология растений. 2008. Т. 55. № 5. C. $777-785$.
Polovnikova M.G. Aktivnost' komponentov antioksidantnoj zashchity $i$ polifenoloksidazy u gazonnyb rasteniju ontogeneze $v$ usloviyah gorodskoj sredy // Fiziologiya rastenij. [Plant physiology]. 2008 Vol. 55. №5. pp. 777-785.

11. Гусакова С.В.,. Ковалев И.В, Смаглий Л.В. Газовая сигнализация в клетках млекопитающих // Успехи физиологических наук. 2015. T. 46. № 4 . C. 53-73.

Gusakova S.V... Kovalev I.V, Smaglii L.V. Gazovava signalizaciva v kletkah mlekopitayushchih // Uspekhi fiziologicheskih nauk. 2015. Vol. 46. № 4. pp. 53-73. (in Russian)

12. Balazy M. Abu-Yousef I.A. Harpp D.N., Park J. Identification of carbonyl sulfide and sulfur dioxide in porcinecoronary artery by gas chromatography/mass spectrometry, possible relevance to EDHF // Biochemical and Biophysical Research Communications 2003. Vol. 311. P. $728-734$.

13. Сукманский О.И., Реутов В.П. Газотрансмиттеры: физиологическая роль и участие в патогенезе заболеваний // Успехи физиологических наук. 2016. Т. 47. № 3. С. 30-58.

Sukmanskij O.I., Reutov V.P. Gazotransmittery: fiziologicheskava rol' $i$ uchastie v patogeneze zabolevanij // Uspekhi fiziologicheskih nauk. 2016. Vol. 47. № 3. pp. 30-58. (in Russian)

14. Thomas D., Surdin-Kerjan Y. Metabolism of sulfur amino acids in Saccharomyces cerevisiae // Microbiol. Mol. Biol. Rev. 1997. Vol.61 (4). P. 503-532.

15. Нилов В.И., Скурихин И.М. Химия виноделия / 2-е изд., доп. и пер. М.:Пищевая промышленность, 1967. 441 с.

Nilov V.I., Skurihin I.M. Himiya vinodeliva [The Chemistry of Winemaking] / 2-nd ed. M.: Pishchevaya promyshlennost', 1967. 441 p. (in Russian)

16. Качалкин А.В., Абдуллабекова Д.А., Магомедова Е.С. и др. Дрожжевые грибы виноградников Дагестана и других регионов // Микробиология. 2015. Т. 84. № 3. С. 360-368. doi10.1134/ S002626171503008X

Kachalkin A.V., Abdullabekova D.A., Magomedova E.S et al. Yeasts of the vineyards in Dagestan and other regions // Microbiology. 2015. Vol .84. no.3. pp.425-432.

17. Абдуллабекова Д.А., Магомедова Е.С., Магомедов Г.Г. и др. Дрожжевые сообщества каштановых почв под виноградниками Дагестана // Почвоведение. 2017. №12. С. 1494 -1498. doi 10.1134/ S1064229317110023

Abdullabekova D. A., Magomedova E. S., Magomedov G. G et al. Yeast Communities of Chestnut Soils under Vinevards in Dagestan // Eurasian Soil Science. 2017. Vol.50. no.12. pp.1463-1467.

18. Kurtzman C.P. Fell J.W., Boekhout T. The yeasts, a taxonomic study / 5th edition. Amsterdam et al.: Elsevier, 2011. 2080 p.

19. Гержикова В.Г. Методы технохимического контроля в виноделии / Под редакцией В.Г. Гержиковой. Симферополь: Таврида. $2009.30 \mathrm{c}$

Gerzhikova V.G. Metodv tekhnobimicheskogo kontrolva v vinodelii [Methods of technical and chemical control in winemaking]/ Ed. by V.G. Gerzhikova. Simferopol': Tavrida. 2009. 30 p. (in Russian)

20. Яшин А.Я. Новый прибор «Цвет Яуза 01-АА» для определения суммарного содержания антиоксидантов в пищевых продуктах БАДах // Мир измерений. 2008. № 2. С. 56-60.

Ashin A.YA. Novyj pribor "Cvet Yauza 01-AA» dlya opredeleniya summarnogo soderzhaniva antioksidantov $v$ pishchevyh produktah. BADab" // Mir izmerenij. 2008. № 2. pp. 56-60. (in Russian)

21. Rhee S.G. Cell signaling. $\mathrm{H}_{2} \mathrm{O}_{2}$, a necessary evil for cell signaling // Science. 2006. №312. P.1882-1883.

22. Коновалов С.А. Биохимия дрожжей. М.:Пищевая пром-ть, 1980. 271 с

Konovalov S.A. Biobimiva drozhzhej [Yeast biochemistry] M.:Pishchevaya prom-t', 1980. 271 p. (in Russian)

23. Глазунов А.И., Царану И.Н. Технология вин и коньяков. / А.И. Глазунов., И.Н. Царану. М.:Агропромиздат, 1988. 342 с.

Glazunov A.I., Caranu I.N. Tekbnologiya vin i kon'yakov / A.I. Glazunov., I.N. Caranu. M.:Agropromizdat, 1988.342 p. (in Russian)

24. Богомолов Б.Д., Сапотницкий С.А., Соколов О.М. и др. Переработка сульфатного и сульфитного щелоков: Учебник для вузов. М.: Лесная промышленность, 1989. 360 с.

Bogomolov B.D., Sapotnickij S.A., Sokolov O.M. et al. Pererabotka sul'fatnogo $i$ sul'fitnogo shchelokov: Uchebnik dlya vuzov. M. Lesnaya promyshlennost', 1989. 360 p. (in Russian) 